\title{
Productive and reproductive performances of Santa Inês ewes fed diets supplemented with protected fat in the postpartum
}

\author{
Marcos Paulo dos Santos(1), Marcelo Marcondes de Godoy ${ }^{(2)}$, Cleber Luiz de Sousa ${ }^{(2)}$, \\ Roberta de Moura Assis ${ }^{(3)}$ and Cassius Vinicius Barbosa Sena ${ }^{(4)}$
}

\begin{abstract}
(1)Universidade Federal de Goiás (UFG), Escola de Agronomia, Rodovia GO-462, Km 0, Campus Samambaia, CEP 74690-900 Goiânia, GO, Brazil. E-mail: marcospaulo_agronomo@hotmail.com ${ }^{(2)}$ Instituto Federal Goiano, Rodovia GO-154, Km 03, Campus Ceres, Zona Rural, CEP 76300-000 Ceres, GO, Brazil. E-mail: marcondes.godoy@hotmail.com, cleber18luiz@hotmail.com (3)UFG, Escola de Veterinária e Zootecnia, Rodovia BR-364, Km 192, Campus Jataí, CEP 75801-615 Jataí, GO, Brazil. E-mail: roberta.assis@yahoo.com.br (4)Rua dos Pica-Paus, no 1.750, Nova Uberlândia, CEP 38412-641 Uberlândia, MG, Brazil. E-mail: cassiusvet@hotmail.com
\end{abstract}

\begin{abstract}
The objective of this work was to evaluate the effect of the inclusion of protected fat in the concentrate on the productive and reproductive performances of Santa Inês ewes in feedlot, up to 60 days after parturition. Thirty-six pregnant Santa Inês ewes, with an average age of 24 months and initial weight of $46.54 \pm 7.87 \mathrm{~kg}$, were used. A completely randomized experimental design was used, with three treatments: CS, concentrated supplement; G5, concentrated supplement with 5.5\% protected fat (PF); and G10, concentrated supplement with $13.5 \%$ PF. The productive performance parameters were evaluated every two weeks. At 60 days after parturition, the chemical composition of milk and the reproductive parameters were determined. The inclusion of PF in the concentrate did not affect the following variables: body weight, body condition score, service period, lambing to first estrus interval, and chemical composition of milk. The supplementation with or without PF allowed ewes to keep body weight until 60 days after parturition, which improved their body condition score. The inclusion of PF in the concentrate does not change the productive performance of confined Santa Inês ewes; however, it affects reproduction by resulting in lower probability rates of pregnancy.
\end{abstract}

Index terms: body weight, ovine, polyunsaturated fatty acids, supplementation.

\section{Desempenhos produtivo e reprodutivo de ovelhas Santa Inês alimentadas com dietas suplementadas com gordura protegida no pós-parto}

\begin{abstract}
Resumo - O objetivo deste trabalho foi avaliar o efeito da inclusão de gordura protegida no concentrado sobre os desempenhos produtivo e reprodutivo de ovelhas Santa Inês em confinamento, até 60 dias após o parto. Utilizaram-se 36 ovelhas Santa Inês prenhes, com idade média de 24 meses e peso inicial de 46,5 $\pm 7,9 \mathrm{~kg}$. Utilizou-se o delineamento experimental inteiramente casualizado com três tratamentos: SC, suplemento concentrado; G5, suplemento concentrado, com 5,5\% de gordura protegida (GP); e G10, suplemento concentrado, com 13,5\% de GP. Os parâmetros de desempenho produtivo foram avaliados quinzenalmente. Aos 60 dias após o parto, determinaram-se a composição química do leite e os parâmetros reprodutivos. A inclusão de GP no concentrado não influenciou as seguintes variáveis: peso corporal, escore de condição corporal, período de serviço, intervalo do parto ao primeiro estro e composição química do leite. A suplementação com ou sem GP permitiu que as ovelhas mantivessem o peso corporal até 60 dias após o parto, o que melhorou o escore de condição corporal. A inclusão de GP no concentrado não altera o desempenho produtivo de ovelhas Santa Inês confinadas; entretanto, compromete a reprodução por resultar em menores taxas de probabilidade de prenhez.
\end{abstract}

Termos para indexação: peso corporal, ovinos, ácidos graxos poli-insaturados, suplementação.

\section{Introduction}

Adjusting the quantity and quality of the diet is the main way of maximizing the digestive capacity of animals, allowing the genetic potential of the breed to be reached. One way to meet these nutritional requirements is adding larger amounts of soluble carbohydrates. However, this practice may compromise fiber intake, besides increasing the acidity of the rumen and causing metabolic disorders. 
The inclusion of lipids in the diets of ruminants is an alternative to avoid these effects, since it positively affects weight gain by contributing to an increase in the energy available to be metabolized and converted into body mass by animals, which improves energy balance (Valinote et al., 2006).

In Brazil, the most used lipid sources are soybean grain and cotton, in addition to their by-products; however, fatty acids from these sources have a slow release and are easily converted in the rumen into volatile compounds with a low energy density (Valinote et al., 2006). Other sources are protected fats (calcic salts of long-chain fatty acids). Protected fat is relatively inert in the rumen and acts only in the $\mathrm{pH}$ conditions of the abomasum; it also presents a high energy density and does not affect the use of dietary fiber (Neumann et al., 2015).

The positive effect of providing calcium salts of fatty acids on ewe weight at postpartum was reported by Bona Filho et al. (1994). The inclusion of fatty acids in the diet of ruminants, besides being a resource for improving production parameters, such as weight and body condition score (Moura Filho et al., 2005), can also be used to increase the reproductive efficiency of animals (Gressler \& Souza, 2009).

According to Sartori \& Guardiero (2010), after being absorbed, polyunsaturated fatty acids promote an increase in luteinizing hormone pulsatility and the growth of preovulatory follicles in cows, which increases the circulating concentration of prostaglandins and steroid hormones. Another important function of polyunsaturated fatty acids is decreasing the hepatic metabolism of these hormones (Hawkins et al., 1995), which may shorten the period between conception and birth, consequently increasing the fertility of the herd.

The production and quality of milk may also be changed by the consumption of high energy diets. Lactating ewes transfer fatty acids from the diet directly into their milk due to the metabolic priority exerted by the mammary glands (Silva et al., 2015). In this sense, supplying protected fat to lactating ewes may increase the milk fat content, improving the performance of the lambs. However, this increase depends on factors such as the level of inclusion in the concentrate, stage of lactation, and roughage:concentrate ratio.

Fatty acids also play a key role in the formation of keratin. In the udder, keratin, besides being a physical barrier, may inactivate some bacteria by electrostatic bonding with the cell wall of the pathogen, altering the permeability of the membrane and making pathogens more susceptible to osmotic pressure (Carneiro et al., 2009). This mechanism may reduce the number of somatic cells mobilized to fight microorganisms and, therefore, improve milk quality (Pales et al., 2005).

This way, the intake of polyunsaturated fatty acids, in the form of protected fat as an energy source, could have a positive effect on the performance of lactating Santa Inês ewes.

The objective of this work was to evaluate the effect of the inclusion of protected fat in the concentrate on the production and reproductive performances of Santa Inês ewes in feedlot, up to 60 days after parturition.

\section{Materials and Methods}

The experiment was conducted at the sheep sector of Instituto Federal Goiano, in the municipality of Ceres, in the state of Goiás, Brazil, from October 2010 to June 2011. Prior to the beginning of the study, 68 Santa Inês ewes, single and not pregnant, were subjected to estrus synchronization by an intramuscular injection of two 0.263-mg doses of cloprostenol sodium (Sincrocio, Laboratório Ouro Fino, Cravinhos, SP, Brazil) at intervals of 11 days, in order to concentrate lambing.

Ewes were subjected to interspersed, controlled and assisted breeding with three breeding rams, which underwent clinical and andrological evaluation. Both ewes and rams received an application of $1 \mathrm{~mL}$ per $20 \mathrm{~kg}$ body weight of the anthelmintic albendazole (Valbazen 10, Pfizer, São Paulo, SP, Brazil) and of $2 \mathrm{~mL}$ of a polyvalent vaccine (Polistar, Vallée, Uberlândia, MG, Brazil), subcutaneously, against clostridial diseases, during the early breeding period. At 45 days after controlled breeding, the diagnosis of pregnancy was performed by transrectal ultrasound with a $5-\mathrm{Hz}$ probe using the Aloka SSD 500 ultrasound device (Aloka Co., Ltd., Tokyo, Japan). During pregnancy, ewes were handled in Guinea grass (Panicum maximum) pickets with unrestricted access to mineral salt and water until they started to receive the experimental diets.

The concentrate was gradually supplied for 15 days before the scheduled date for parturition, and the supply was increased every 5 days by $30 \%$ of the total to be consumed, in order to adapt the ewes to the facilities and to the concentrated diet. 
Thirty-six multiparous ewes were selected at parturition, with an average age of 24 months and initial body weight of $46.5 \pm 7.9 \mathrm{~kg}$. The choice of the animals to be evaluated in each previously adapted group was made according to the standard deviation of weight and body condition score (BCS) and to lambing type (single or twin). Twelve animals were used per treatment, so that the differences among groups were similar as to the respective variables. For the experimental evaluations (postpartum), the selected ewes were kept confined in covered collective cages, with a drinking vessel and a trough, in order to receive the diets for 60 days.

The 36 pregnant ewes were randomly distributed into three treatment groups, in a completely randomized experimental design with 12 replicates (animals) per treatment. The treatments were as follows: CS, concentrated supplement; G5, concentrated supplement with $5.50 \%$ inclusion of protected fat (PF); and G10, concentrated supplement with $13.50 \%$ inclusion of PF (Table 1). The following productive and reproductive parameters were evaluated: weight and BCS, postpartum interval, interval from lambing to first estrus, pregnancy index, energy value, and chemical composition and somatic cell count (SCC) of milk.

The diets fed to the ewes were balanced according to Alderman \& Cottrill (1993), in order to be isonitrogenous and isocaloric (Table 1). Corn silage and the concentrates of the experimental diets were supplied as complete diets twice a day, at $08 \mathrm{~h} 00$ and 17h30, for all ewe groups, which remained with their lambs in feedlots during the experimental period. The height of the trough was adjusted so that the lambs had no access to the diet.

Samples of the experimental diets were collected weekly and then stored in a freezer at $-20^{\circ} \mathrm{C}$. At the end of the experiment, the samples were thawed, homogenized, and analyzed in order to determine dry matter (DM), organic matter (OM), crude protein (CP), ether extract (EE), neutral detergent fiber (NDF), and acid detergent fiber (ADF) according to Horwitz et al. (1999). Total digestible nutrients (TDN) were estimated by the equation $\mathrm{TDN}=77.13-0.425 \mathrm{ADF}$ (Cappelle et al., 2001) for a better fit to the data of the present study.

Body weight was evaluated by weighing ewes every 15 days from lambing to 60 days postpartum, early in the morning, prior to feeding. The BCS was evaluated 60 days after parturition by assigning values from 1 to 5 , in which 1 corresponds to very lean animals and 5 to obese animals (Caldeira \& Vaz Portugal, 1998).

The experimental data related to ewe weight and body condition were analyzed as plots subdivided in time $(0,15,30,45$, and 60 days postpartum), in a completely randomized design by the analysis of variance, according to the model: $\mathrm{Y}_{\mathrm{ijk}}=\mu+\mathrm{T}_{\mathrm{i}}+(\mathrm{O} / \mathrm{T})_{\mathrm{ij}}+\mathrm{D}_{\mathrm{k}}+(\mathrm{T} \times \mathrm{D})_{\mathrm{ik}}+\varepsilon_{\mathrm{ijk}}$, in which $\mathrm{Y}_{\mathrm{ijk}}$ is the response variable (weight and score) of ewe $\mathrm{j}$ of treatment $\mathrm{i}$ at time $\mathrm{k} ; \mu$ is a constant; $\mathrm{T}_{\mathrm{i}}$ is the effect of treatment $i$, in which $\mathrm{i}=0,5$, and $10 \% \mathrm{PF}$ in the concentrate; $(\mathrm{O} / \mathrm{T})_{\mathrm{ij}}$ is the effect of sheep $\mathrm{j}$ in treatment $\mathrm{i}$ (residue a); $D_{k}$ is the effect of postpartum day $k$, so that $\mathrm{k}=0,15,30,45$, and $60 ;(\mathrm{T} \times \mathrm{D})_{\mathrm{ik}}$ is the effect of

Table 1. Composition of total experimental diets supplied to Santa Inês ewes in feedlots.

\begin{tabular}{|c|c|c|c|}
\hline \multirow[t]{2}{*}{ Ingredient } & \multicolumn{3}{|c|}{ Percentage $(\%)$} \\
\hline & $\mathrm{CS}$ & G5 & G10 \\
\hline$\overline{\text { Corn silage }}$ & 43.61 & 50.77 & 61.39 \\
\hline Ground corn grain & 37.18 & 25.60 & 12.13 \\
\hline Soybean meal & 16.92 & 18.71 & 19.31 \\
\hline Megalac-E $E^{(1)}$ & 0.00 & 2.72 & 5.21 \\
\hline Mineralized salt ${ }^{(2)}$ & 2.26 & 2.17 & 1.93 \\
\hline \multirow[t]{2}{*}{ Monensin sodium } & 0.03 & 0.03 & 0.03 \\
\hline & \multicolumn{3}{|c|}{ Nutritional composition (\%) } \\
\hline Dry matter & 58.11 & 52.75 & 50.25 \\
\hline Organic matter & 93.68 & 93.86 & 94.64 \\
\hline Crude protein & 10.57 & 13.54 & 13.35 \\
\hline Neutral detergent fiber & 31.03 & 38.83 & 32.95 \\
\hline Acid detergent fiber & 15.71 & 17.91 & 16.94 \\
\hline Ether extract & 2.43 & 2.34 & 2.89 \\
\hline Ash & 6.32 & 6.14 & 5.36 \\
\hline \multirow[t]{2}{*}{ Total digestible nutrients ${ }^{(3)}$} & 70.45 & 69.52 & 69.93 \\
\hline & \multicolumn{3}{|c|}{ Quantity per ewe $(\mathrm{g})$} \\
\hline Concentrated supplement & 900 & 800 & 600 \\
\hline Protected fat (PF) & - & 44 & 81 \\
\hline PF in the supplement $(\%)$ & & 5.5 & 13.5 \\
\hline Concentrate:fat ${ }^{(4)}$ & - & 2.27 & 2.47 \\
\hline
\end{tabular}

(1)Megalac-E (Church \& Dwight Co., Inc., Ewing, NJ, USA). (2)Mineralized salt (Guabiphos Ovinos AE, Guabi Nutrição e Saúde Animal S.A., Campinas, SP, Brazil): $140 \mathrm{~g}$ calcium; $65 \mathrm{~g}$ phosphorus; $10 \mathrm{~g}$ magnesium; $130 \mathrm{~g}$ sodium; $80 \mathrm{mg}$ cobalt; $1,000 \mathrm{mg}$ iron; $60 \mathrm{mg}$ iodine; $3,000 \mathrm{mg}$ manganese; $10 \mathrm{mg}$ selenium; 5,000 mg zinc; 50,000 IU vitamin A; and 312 IU vitamin E. ${ }^{(3)}$ Total digestible nutrients (TDN) estimated by the ratio between TDN and acid detergent fiber in total diets according to the equation by Cappelle et al. (2001). ${ }^{(4)}$ Ratio of concentrate substitution by PF in treatments with 5.5 and $13.5 \%$ PF. CS, concentrated supplement; G5, concentrated supplement with $5.5 \% \mathrm{PF}$; and G10, concentrated supplement with $13.5 \% \mathrm{PF}$. 
the interaction of PF levels $\times$ days postpartum; and $\varepsilon_{\mathrm{ijk}}$ is the random error related to the $Y_{\mathrm{ijk}}$ observation. The analysis of variance was followed by the regression analysis for sources with a significant variation $(p<0.05)$. In the model, the inclusion levels of PF in the concentrate, postpartum days, and the interaction between them were considered as fixed effects.

The period between lambing and the first estrus and the postpartum interval of ewes were evaluated as the time in days from parturition to the next pregnancy. Estrus detection was carried out daily from the tenth day after parturition using four rams painted with ink along their chests, so that, at the time of mounting, the female's rump was marked. Ewes in estrus were directed to the breeding cage and mounted three times through assisted and controlled breeding at intervals of 12 hours. Three Santa Inês breeding rams were used interchangeably to avoid tiring the animals.

The diagnosis of pregnancy was performed by rectal ultrasonography 45 days after controlled breeding. The response variable of the diagnosis of pregnancy is dichotomous: $\mathrm{P}$, pregnant; and $\mathrm{E}$, empty. Data resulting from this type of analysis may come from a binomial distribution, with p probability, which is the probability of occurrence, and mi probability, of nonoccurrence of the event, as follows: yi $\sim \operatorname{Bin}(\mathrm{mi}, \pi \mathrm{i})$. To obtain the probability model for the matrices to be classified as pregnant (1) and as empty (0), an analysis was performed based on the logistic regression method using the GLM procedure of the R statistical software (R Core Team, 2016). The logistic model used was: $\mathrm{Pi}=\mathrm{e} /\left(1+\mathrm{e}^{\prime}\right)$, an equation for which $\mathrm{e}=\mu+\sum_{=0}^{1} \beta_{1}(\mathrm{PF})^{\mathrm{i}}$, in which $\mu$ is the constant inherent to all observations and $\beta_{1}$ is the regression coefficient of the PF level included in the concentrate. The significance of the effect of the independent variable (PF level in the concentrate) was tested adopting a confidence interval of $5 \%$ probability.

At 60 days after lambing, five sheep were randomly chosen from each group for sampling and evaluation of the chemical composition of milk and its energy value $\left(\mathrm{MJ} \mathrm{kg} \mathrm{kg}^{-1}\right)$. After the separation of the lambs for 4 hours, the ewes were milked by hand, drawing approximately $50 \mathrm{~mL}$ of milk from each ewe, in order to determine the concentrations of fat, lactose, protein, total dry extract, defatted dry milk extract, and SCC. The amount of energy ( $\mathrm{MJ} \mathrm{kg}^{-1}$ milk) was determined according to Alderman \& Cottrill (1993) by the equation: $0.04194 \times \mathrm{FAT}+0.01585 \times \mathrm{PROT}+$ $0.02141 \times \mathrm{LACT}$, in which FAT is the amount of fat in the milk $\left(\mathrm{g} \mathrm{kg}^{-1}\right)$, PROT is the amount of protein in the milk $\left(\mathrm{g} \mathrm{kg}^{-1}\right)$, and LACT is the amount of lactose in the milk $\left(\mathrm{g} \mathrm{kg}^{-1}\right)$. Because they do not follow a normal distribution, SCC values were transformed to $\log 10$ as in Guaraná et al. (2011).

Because of the PF inclusion level in the concentrate, the following variables were subjected to the analysis of variance, followed by the regression analysis: period from lambing to first estrus, postpartum interval, chemical composition of milk (fat, protein, lactose, total dry extract, and defatted dry extract), SCC log, and milk energy value. Statistical analyses were performed using the R software, version 3.2.4 (R Core Team, 2016).

\section{Results and Discussion}

Weight and BCS were not affected by PF levels in the concentrate or by the interaction between PF levels $\times$ postpartum days during the experimental period (Table 2). The supplementation of lactating ewes allowed the maintenance of body weight at postpartum as a result of proper food handling, especially during the productive period, which contributed to the fast return to the reproductive activity.

According to Emediato et al. (2009a), Bergamácia ewes fed a diet supplemented with $35 \mathrm{~g}$ per day of $\mathrm{PF}$ in the concentrate also presented, at 60 days after

Table 2. Summary of the analysis of variance for the variables body weight and body condition score of Santa Inês ewes kept in feedlots and fed a diet supplemented with different levels of protected fat in the concentrate, as well as days after lambing.

\begin{tabular}{lcccccc}
\hline Source of variation & \multicolumn{2}{c}{ Body weight } & & \multicolumn{2}{c}{ Body score } \\
\cline { 2 - 3 } \cline { 5 - 6 } & $\mathrm{F}$ & $\mathrm{p}$-value & & $\mathrm{F}$ & $\mathrm{p}$-value \\
\hline Supplement $^{(1)}$ & 0.42 & $0.6596^{\mathrm{ns}}$ & & 0.97 & $0.389974^{\mathrm{ns}}$ \\
DAC $^{(2)}$ & 12.32 & $0.0000^{* * *}$ & & 5.86 & $0.00023^{* * *}$ \\
Supplement x DAC & 0.47 & $0.8728^{\mathrm{ns}}$ & & 0.74 & $0.6563^{\mathrm{ns}}$ \\
\hline $\mathrm{CV}(\%)^{(3)}$ & \multicolumn{3}{c}{36.6} & & 36.5 \\
CV (\%) & \multicolumn{3}{c}{3.5} & & \multicolumn{2}{c}{13.7} \\
General average & \multicolumn{3}{c}{45.5} & & 3.3 \\
\hline
\end{tabular}

${ }^{(1)}$ Supplements equivalent to $0,5.5$, and $13.5 \%$ inclusion of protected fat in the concentrate. ${ }^{(2)} \mathrm{DAC}, 0,15,30,45$, and 60 days after lambing. ${ }^{(3)}$ Coefficient of variation in plots (supplement). ${ }^{(4)}$ Coefficient of variation in subplots (days after lambing). ${ }^{* * *}$ Significant at $0.1 \%$.. 
parturition, body weight values similar to those of ewes supplemented with the concentrate without the inclusion of PF. Corriedale and Ideal ewes, supplemented with a diet containing $80 \mathrm{~g}$ PF per day in the concentrate, during the first 45 days postpartum, performed better than those that received a supplement without PF (Bona Filho et al., 1994).

This divergence in the dynamics of postpartum weight can be explained by the amount of PF consumed and by the fact that some breeds may be more responsive than others to PF inclusion in the concentrate. In the present study, the supply of 44 and $81 \mathrm{~g}$ PF per sheep in the G5 (5.50\%) and G10 (13.50\%) groups, respectively, did not alter the dynamics of body weight compared with the CS group. This is an indication that Santa Inês ewes require levels higher than those recommended in the present study or that they may not be responsive to $\mathrm{PF}$ inclusion in the concentrate.

The inclusion of PF in the concentrate was able to increase the roughage:concentrate ratio for G5 and G10 (Table 1). For each gram of PF added to the concentrate, it was possible to replace 2.27 and $2.47 \mathrm{~g}$ of the concentrate in G5 and G10, respectively, compared with the CS. The increase in the roughage:concentrate ratio by the inclusion of $\mathrm{PF}$ in the diet is desirable, especially for ewes kept in feedlots, since it allows lowering respiration rate and rectal temperature, consequently reducing thermal stress, which may compromise the performance of animals (Jochims et al., 2010).

Over the postpartum days, there was a change in the body weight and BCS of ewes (Figures 1 and 2). In all diets, the body weight of ewes showed a quadratic behavior, with a reduction during the lambing period up to 40 days postpartum, followed by a recovery at the end of the experimental period (Figure 1). Emediato et al. (2009a) also observed weight gains for Bergamácia ewes 60 days after postpartum, regardless of the inclusion of PF in the concentrate. For lactating ewes, weight loss is attributed to the difficulty in providing nutrients for feeding in amounts suitable for the matrices during this phase, since the energy demand increases more rapidly than the dry matter intake; therefore, the ewes use energy reservations to produce milk and stop accumulating body mass (Araújo et al., 2008).

The recovery of the body weight of ewes at the end of the experimental period was due to the nearing of the weaning period (60 days postpartum). At the final stage of lactation, there is a reduction in the energy demand for the production of milk, which directs the energy absorbed from the diet to other metabolic functions of the body, such as the growth and the division of muscle cells and of the adipose tissue, which causes an increase in the body mass of animals.

The BCS of ewes followed a positive linear tendency throughout the experimental period (Figure 2). This increase in BCS, regardless of PF inclusion levels in the concentrate, can be explained by the resumption of the weight gain of ewes (Figure 1), since BCS improvements are directly related to increases in the body weight of animals. Afonso et al. (2010) reported increases in BCS values of Santa Inês ewes fed a diet supplemented with $30 \mathrm{~g}$ PF per day, compared with those that received supplementation without PF, which is alignment with the results of the present study.

The PF levels in the concentrate did not affect the period from lambing to estrus and the postpartum interval (Table 3). However, the probability of pregnancy decreased when PF was included in the concentrate (Figure 3). Costa et al. (2011) supplemented the diet of Santa Inês ewes with PF (3.75\% DM of PF) up to 25 and 60 days after lambing, and also found no differences, compared with the control treatment, for

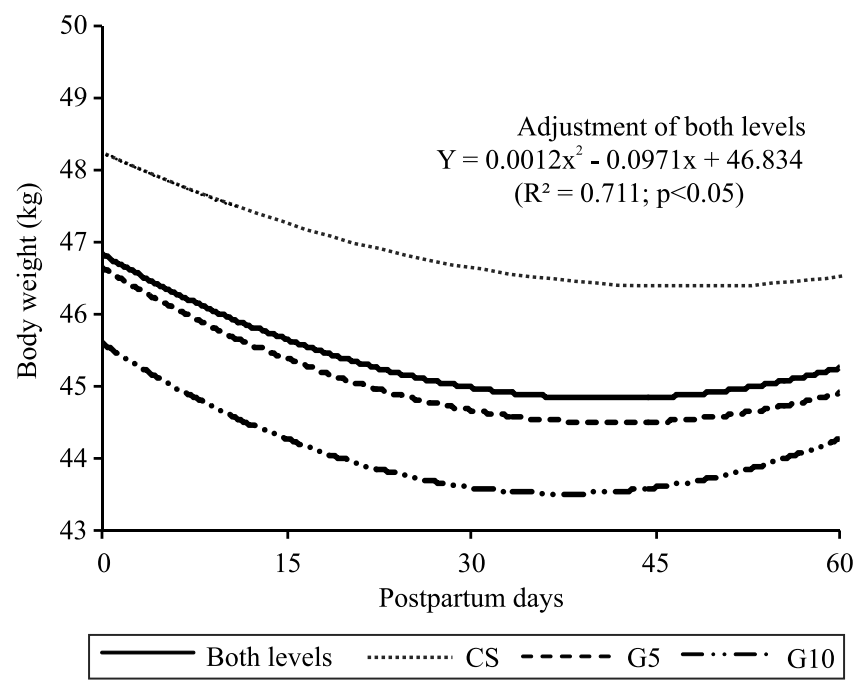

Figure 1. Effect of postpartum period on the body weight of Santa Inês ewes kept in feedlots and fed a diet supplemented with different levels of protected fat (PF). CS, G5, and G10 are equivalent to $0,5.5$, and $13.5 \%$ inclusion of $\mathrm{PF}$ in the concentrate, respectively. 
the average period from lambing to estrus $(32.4,27.2$, and 35.5 days) and the postpartum interval (45.2, 46.5, and 45.2 days), respectively.

Nutrition has a direct effect on reproductive functions. Well-fed animals have better body weight and body conditions than malnourished animals and, consequently, have a favorable hormonal balance so that processes such as folliculogenesis and steroidogenesis occur faster (Santos et al., 2008).

Reproductive processes, such as uterine involution and the restoration of the postpartum estrus cycle, depend on the amount of PGF $2 \alpha$ in the animal's metabolism. The production of this involution can be altered by supplementation with PF (Funston, 2004). Polyunsaturated fatty acids, particularly those of the omega-6 family, present in PF, when metabolized in the intestine, can be directed to the formation of arachidonic acid, a precursor of PGF $2 \alpha$, which, when reaching the plasma, is directed to the reproductive organs, affecting the reproductive performance of the animal. However, the excessive increase in the production and release of PGF2 $\alpha$ after parturition may lead to luteolysis and increased embryo mortality (Petit et al., 2002; Funston, 2004). In the present study, $\mathrm{PF}$ inclusion in the concentrate may have altered

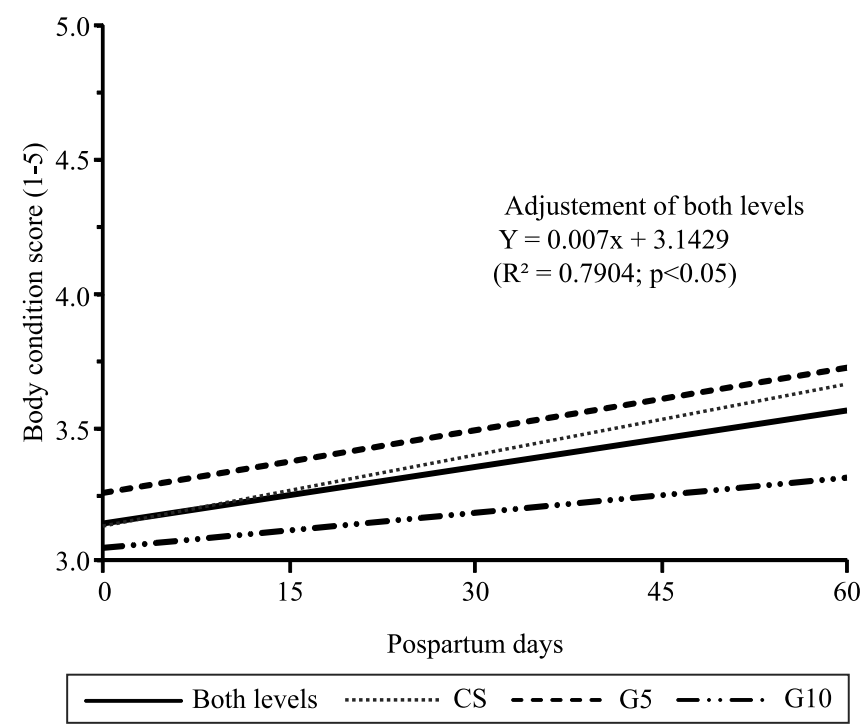

Figure 2. Evolution of body condition score of Santa Inês ewes kept in feedlots and fed a diet supplemented with different levels of protected fat (PF) during the postpartum period. CS, G5, and G10 are equivalent to $0,5.5$, and $13.5 \%$ inclusion of PF in the concentrate, respectively. prostaglandin production, which reached levels higher than those of animals without PF, causing luteolysis and, consequently, embryonic death, reducing the probability of pregnancy.

There was no effect of diets on the milk composition of ewes (Table 4). Among the causes responsible for changes in the chemical composition of milk, stress by environmental factors and the energy density of the diets stand out. The latter can be modified by the inclusion of energy sources such as lipids and fatty acids (Paula et al., 2012).

Generally, the supplementation of ewes with the inclusion of fat by up to $4-5 \%$ DM results in increased milk fat. However, high concentrations may lead to the depression of fat levels (Bauman \& Griinari, 2003).

Table 3. Zootechnical reproductive indexes of lactating Santa Inês ewes kept in feedlots and fed a diet supplemented up to 60 days after lambing.

\begin{tabular}{|c|c|c|c|c|c|}
\hline \multirow[t]{2}{*}{ Variable } & \multicolumn{3}{|c|}{ Supplement $^{(1)}$} & \multirow{2}{*}{$\begin{array}{l}\text { Regression } \\
(\mathrm{Y}) ; \mathrm{R}^{2}\end{array}$} & \multirow{2}{*}{$\begin{array}{l}\text { CV } \\
(\%)\end{array}$} \\
\hline & $\mathrm{CS}(\mathrm{n}=12)$ & G5 $(n=11)$ & $\overline{G 10(n=12)}$ & & \\
\hline PCFE (days) & 46.80 & 47.80 & 47.30 & $47.3 ;{ }^{\text {ns }}$ & 16.64 \\
\hline PPI (days) & 52.50 & 52.00 & 49.50 & $51.3 ;{ }^{\mathrm{ns}}$ & 14.55 \\
\hline
\end{tabular}

(1) Supplement: CS, G5, and G10 are equivalent to 0, 5.5, and $13.5 \%$ inclusion of protected fat in the concentrate, respectively. PCFE, period from lambing to first estrus; and PPI, postpartum interval. ${ }^{\text {ns Nonsignificant. }}$

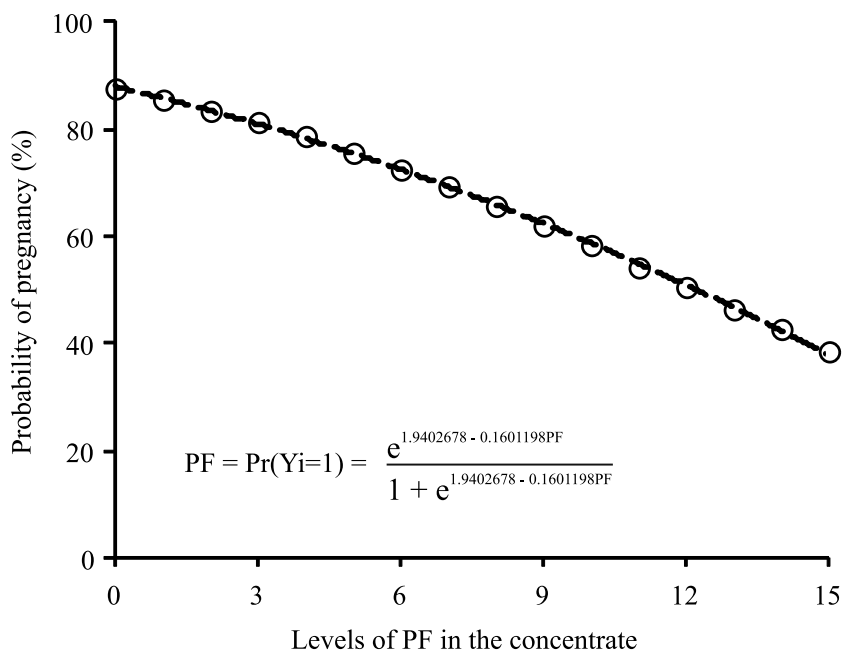

Figure 3. Relationship between the probability of pregnancy of Santa Inês ewes kept in feedlots and fed a supplemented diet during the postpartum period and the inclusion level of protected fat $(\mathrm{PF})$ in the concentrate. 
Table 4. Means and coefficients of variation (CV) of chemical composition, energy value, and log of the somatic cell count of milk from Santa Inês ewes kept in feedlots and fed a supplemented diet up to 60 days after lambing.

\begin{tabular}{|c|c|c|c|c|c|c|}
\hline \multirow[t]{2}{*}{ Variable } & \multicolumn{3}{|c|}{ Supplement $^{(1)}$} & \multirow[t]{2}{*}{ Regression (Y) } & \multirow[t]{2}{*}{$\mathrm{R}^{2}$} & \multirow{2}{*}{$\begin{array}{l}\text { CV } \\
(\%)\end{array}$} \\
\hline & $\mathrm{CS}(\mathrm{n}=5)$ & G5 $(n=5)$ & $\mathrm{G} 10(\mathrm{n}=5)$ & & & \\
\hline Fat & 6.91 & 7.64 & 6.60 & 7.05 & ns & 12.00 \\
\hline Protein & 5.15 & 5.10 & 5.10 & 5.12 & ns & 11.00 \\
\hline Lactose & 4.85 & 4.79 & 4.60 & 4.75 & ns & 4.72 \\
\hline Total dry extract & 17.85 & 18.50 & 17.39 & 17.91 & ns & 6.73 \\
\hline Defatted dry extract & 10.90 & 10.80 & 10.70 & 10.80 & ns & 3.92 \\
\hline Energy value $\left(\mathrm{MJ} \mathrm{kg}^{-1}\right)$ & 4.75 & 4.84 & 4.62 & 4.74 & ns & 9.50 \\
\hline SCC $\log$ & 2.88 & 2.67 & 2.74 & 2.76 & ns & 18.33 \\
\hline
\end{tabular}

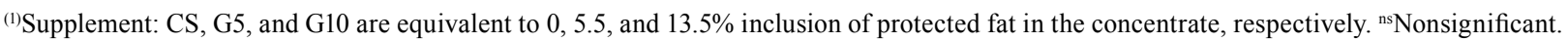

According to Haaland et al. (1981), if the inclusion of fat in the diet is less than $6 \% \mathrm{DM}$, reductions in dry matter intake (DMI) may occur only to meet energy requirements, as observed in diets without the inclusion of fat. With inclusion above this critical value, fiber degradation is reduced, which could explain the decrease in DMI, since there is a reduction in the breakage rate of particles and, therefore, in their escape from the rumen, where the digesta remains for a longer time.

Even if $\mathrm{PF}$ is used, which does not hinder fiber digestion in the rumen, values above $6 \%$ tend to reduce DMI (Souza et al., 2009). This happens because polyunsaturated fatty acids from products, such as Megalac-E, can increase the levels of hormones similar to glucagon (glucagon-like-peptide-1) in the plasma (Relling \& Reynolds, 2007), which exerts a hypophagic effect because it sends a signal to the central nervous system indicating that the animal does not need to eat more. This satiety mechanism is known as a chemostat because it includes the participation of blood metabolites. Therefore, the inclusion of shortchain fatty acids (such as acetic acid, generated from fiber degradation) is reduced when fat is formed in the mammary glands and, consequently, the total content of milk fat is also reduced (Haaland et al., 1981).

In the present study, there was no decrease in milk fat content due to the inclusion of PF in the diet (Table 4). This shows that DMI was possibly not affected by the supply of PF in the concentrate 60 days after lambing, due to the great need for nutrient uptake by lactating ewes. Similar results were observed by Emediato et al. (2009b) and Stradiotto et al. (2010), who used a supplementation of $35 \mathrm{~g}$ PF (Megalac-E) per day in the diet of Bergamácia ewes up to 60 days after parturition. Silva et al. (2007) found a decrease in crude protein and lactose and an increase in milk fat levels as PF levels were increased to $6 \% \mathrm{DM}$ in the concentrate.

The SSC of milk was not affected by the inclusion of PF in the concentrate (Table 4), which is a further indicative that the fatty acids of the PF included in the concentrate may have been reassigned to other metabolic functions or may not have been enough to cause chemical changes in the udder walls and in milk composition (Pales et al., 2005). Therefore, animals fed a diet supplemented with PF, as well as those that did not received it, had to mobilize cells from somatic tissues to prevent or to fight against possible infections, such as mastitis, in the mammary glands.

The similarity in the chemical composition of milk, body weight, and BCS among diets is an indicative that the inclusion of PF in the concentrate was not capable of improving the energy balance of Santa Inês ewes fed a supplement diet during the postpartum period.

\section{Conclusions}

1. The supply of protected fat in the concentrate, up to 60 days after parturition, does not change the production performance or the chemical composition of milk of Santa Inês ewes.

2. The probability of pregnancy of Santa Inês ewes - confined and fed diets supplemented with protected fat up to 60 days after lambing - is reduced, which makes the use of this supplement impractical even if the source of protected fat has a low cost. 


\section{References}

AFONSO, V.A.C.; COSTA, R.L.D. da; SOARES FILHO, C.V.; CUNHA, E.A. da; PERRI, S.H.V.; BONELLO, F.L.; DAVID, C.M.G. Correlações entre padrões hematológicos, parasitológicos e desempenho animal de ovelhas suplementadas com gordura protegida. Boletim de Indústria Animal, v.67, p.125-132, 2010.

ALDERMAN, G.; COTTRILL, B.R. (Ed.). Energy and protein requirements of ruminants: an advisory manual. Wallingford: CAB International, 1993. 176p.

ARAÚJO, J.A.S.; RIET-CORREA, F.; MEDEIROS, R.M.T.; SOARES, M.P.; OLIVEIRA, D.M.; CARVALHO, F.K.L. Intoxicação experimental por Ipomoea asarifolia(Convolvulaceae) em caprinos e ovinos. Pesquisa Veterinária Brasileira, v.28, p.488-494, 2008. DOI: 10.1590/S0100-736X2008001000008.

BAUMAN, D.E.; GRIINARI, J.M. Nutritional regulation of milk fat synthesis. Annual Review Nutrition, v.23, p.203-227, 2003. DOI: 10.1146/annurev.nutr.23.011702.073408.

BONA FILHO, A.; OTTO, C; BRONDANI, L.F.; SÁ, J.L.; YADA, R.S.; SOTOMAIOR, C.S. Efeitos da utilização de diferentes níveis de sais cálcicos de ácidos graxos no desempenho de ovelhas no pós-parto. Ciências Agrárias, v.13, p.111-117, 1994.

CALDEIRA, R.M.; VAZ PORTUGAL, A. Condição corporal: conceitos, métodos de avaliação e interesse da sua utilização como indicador na exploração de ovinos. Revista Portuguesa de Ciências Veterinárias, v.93, p.95-102, 1998.

CAPPELLE, E.R.; VALADARES FILHO, S. de C.; SILVA, J.F.C. da; CECON, P.R. Estimativas do valor energético a partir de características químicas e bromatológicas dos alimentos. Revista Brasileira de Zootecnia, v.30, p.1837-1856, 2001. DOI: 10.1590/ S1516-35982001000700022.

CARNEIRO, D.M.V.F.; DOMINGUES, P.F.; VAZ, A.K. Imunidade inata da glândula mamária bovina: resposta à infecção. Ciência Rural, v.39, p.1934-1943, 2009. DOI: 10.1590/S010384782009005000106.

COSTA, R.L.D. da; FONTES, R. da S.; CUNHA, E.A. da; BUENO, M.S.; QUIRINO, C.R.; AFONSO, V.A.C.; OTERO, W.G.; SANTOS, L.E. dos; DIAS, Â.J.B. Reproductive performance of Santa Inês ewes fed protected fat diet. Pesquisa Agropecuária Brasileira, v.46, p.663-668, 2011. DOI: 10.1590/ S0100-204X2011000600013.

EMEDIATO, R.M. de S.; SIQUEIRA, E.R. de; STRADIOTTO, M. de M.; MAESTÁ, S.A.; GONÇALVES, H.C. Desempenho de ovelhas da raça Bergamácia alimentadas com dieta contendo gordura protegida. Revista Brasileira de Zootecnia, v.38, p.18121818, 2009a. DOI: 10.1590/S1516-35982009000900025.

EMEDIATO, R.M. de S.; SIQUEIRA, E.R. de; STRADIOTTO, M. de M.; MAESTÁ, S.A.; GOMES, M.I.F.V.; PICCININ, A.; DOMINGUES, V.T.B. Queijo tipo prato de leite de ovelhas alimentadas com dieta contendo gordura protegida. Veterinária e Zootecnia, v.16, p.228-238, 2009b.

FUNSTON, R.N. Fat supplementation and reproduction in beef females. Journal of Animal Science, v.82, p.154-161, 2004.
GRESSLER, M.A.L.; SOUZA, M.I.L. Efeitos da suplementação com gordura protegida sobre a foliculogênese ovariana de ruminantes. Veterinária e Zootecnia, v.3, p.70-79, 2009.

GUARANÁ, E.L. de S.; SANTOS, R.A. dos; CAMPOS, A.G.S.S.; SILVA, N. da S. e; AFONSO, J.A.B.; MENDONÇA, C.L. de. Dinâmica celular e microbiológica do leite de ovelhas Santa Inês acompanhadas durante a lactação. Pesquisa Veterinária Brasileira, v.31, p.851-858, 2011. DOI: 10.1590/ S0100-736X2011001000004.

HAALAND, G.L.; MATSUSHIMA, J.K.; JOHNSON, D.E.; WARD, G.M. Effect of replacement of corn by protected tallow in a cattle finishing diet on animal performance and composition. Journal of Animal Science, v.52, p.696-702, 1981. DOI: $10.2527 /$ jas1981.524696x.

HAWKINS, D.E.; NISWENDER, K.D.; OSS, G.M.; MOELLER, C.L.; ODDE, K.G.; SAWYER, H.R.; NISWENDER, G.D. An increase in serum lipids increases luteal lipid content and alters the disappearance rate of progesterone in cows. Journal of Animal Science, v.73, p.541-545, 1995. DOI: 10.2527/1995.732541x.

HORWITZ, W.; CHICHILO, P.; REYNOLDS, H. Official methods of analysis of the Association of Official Analytical Chemists. $11^{\text {th }}$ ed. Washington: Association of Official Analytical Chemists, 1999. 1051p.

JOCHIMS, F.; PIRES, C.C.; GRIEBLER, L.; BOLZAN, A.M.S.; DIAS, F.D.; GALVANI, D.B. Comportamento ingestivo e consumo de forragem por cordeiras em pastagem de milheto recebendo ou não suplemento. Revista Brasileira de Zootecnia, v.39, p.572-581, 2010. DOI: 10.1590/S1516-35982010000300017.

MOURA FILHO, J.; RIBEIRO, E.L. de A.; SILVA, L. das D.F. da; ROCHA, M.A. da; MIZUBUTI, I.Y.; PEREIRA, E.S.; MORI, R.M. Suplementação alimentar de ovelhas no terço final da gestação: desempenho de ovelhas e cordeiros até o desmame. Semina: Ciências Agrárias, v.26, p.257-266, 2005. DOI: 10.5433/1679-0359.2005v26n2p257.

NEUMANN, M.; HORST, E.H.; BONATO, D.V.; HEKER JUNIOR, J.C.; SILVA, M.R.H. da; MAREZE, J. Desempenho e aspectos quali-quantitavos do leite de vacas Jersey suplementadas com gordura protegida de óleo de palma. ACSA: Agropecuária Científica no Semiárido, v.11, p.1-9, 2015.

PALES, A.P.; SANTOS, K.J.G. dos; FIGUEIRAS, E.A.; MELO, C. de S. A importância da contagem de células somáticas e contagem bacteriana total para a melhoria da qualidade do leite no Brasil. Revista Eletrônica Faculdade Montes Belos, v.1, p.162$173,2005$.

PAULA, E.F.E. de; MAIA, F. de P.; CHEN, R.F.F. Óleos vegetais em nutrição de ruminantes. Revista Eletrônica Nutritime, v.9, p.2075-2103, 2012.

PETIT, H.V.; DEWHURST, R.J.; SCOLLAN, N.D.; PROULX, J.G.; KHALID, M.; HARESIGN, W.; TWAGIRAMUNGU, H.; MANN, G.E. Milk production and composition, ovarian function, and prostaglandin secretion of dairy cows fed omega-3 fats. Journal of Dairy Science, v.85, p.889-899, 2002. DOI: 10.3168/ jds.S0022-0302(02)74147-7.

R CORE TEAM. R: a language and environment for statistical computing. Vienna: R Foundation for Statistical Computing, 
2016. Available at: <https://www.R-project.org/>. Accessed o: Apr. 272016.

RELLING, A.E.; REYNOLDS, C.K. Feeding rumen-inert fats differing in their degree of saturation decreases intake and increases plasma concentrations of gut peptides in lactating dairy cows. Journal of Dairy Science, v.90, p.1506-1515, 2007. DOI: 10.3168/jds.S0022-0302(07)71636-3.

SANTOS, J.E.P.; BILBY, T.R.; THATCHER, W.W.; STAPLES, C.R.; SILVESTRE, F.T. Long chain fatty acids of diet as factors influencing reproduction in cattle. Reproduction in Domestic Animals, v.43, p.23-30, 2008. DOI: 10.1111/j.14390531.2008.01139.x.

SARTORI, R.; GUARDIERO, M.M. Fatores nutricionais associados à reprodução da fêmea bovina. Revista Brasileira de Zootecnia, v.39, p.422-432, 2010. DOI: 10.1590/S151635982010001300047.

SILVA, F.L.M.; POLIZEL, D.M.; FREIRE, A.P.A.; SUSIN, I. Manejo nutricional de ovelhas gestantes e lactantes com ênfase em carboidratos fibrosos e não fibrosos. Revista Agropecuária Técnica, v.36, p.1-8, 2015.
SILVA, M.M.C. da; RODRIGUES, M.T.; BRANCO, R.H.; RODRIGUES, C.A.F.; SARMENTO, J.L.R.; QUEIROZ, A.C. de; SILVA, S.P. da. Suplementação de lipídios em dietas para cabras em lactação : consumo e eficiência de utilização de nutrientes. Revista Brasileira de Zootecnia, v.36, p.257-267, 2007. DOI: 10.1590/S1516-35982007000100030.

SOUZA, A.R.D.L.; MEDEIROS, S.R. de; MORAIS, M. da G.; OSHIRO, M.M.; TORRES JÚNIOR, R.A. de A. Dieta com alto teor de gordura e desempenho de tourinhos de grupos genéticos diferentes em confinamento. Pesquisa Agropecuária Brasileira, v.44, p.746-753, 2009. DOI: 10.1590/S0100-204X2009000700015.

STRADIOTTO, M. de M.; SIQUEIRA, E.R. de; EMEDIATO, R.M. de S.; MAESTÁ, S.A.; MARTINS, M.B. Efeito da gordura protegida sobre a produção e composição do leite em ovelhas da raça Bergamácia. Revista Brasileira de Zootecnia, v.39, p.11541160, 2010. DOI: 10.1590/S1516-35982010000500029.

VALINOTE, A.C.; NOGUEIRA FILHO, J.C.M.; LEME, P.R.; SILVA, S. da L. e; CUNHA, J.A. Fontes de lipídio e monensina sódica na fermentação, cinética e degradabilidade ruminal de bovinos. Pesquisa Agropecuária Brasileira, v.41, p.117-124, 2006. DOI: 10.1590/S0100-204X2006000100016.

Received on December 21, 2015 and accepted on August 15, 2016 